\title{
Entangled Histories: Gender and the Community Mobilisations of the Ezhavas in Colonial Kerala
}

\author{
Kavyasree R \\ Doctoral Fellow, Centre for Women's Studies, University of Hyderabad. E-mail: \\ kavyasreeraghunath@gmail.com. ORCID id: 0000-0002-5399-7217
}

\begin{abstract}
This paper explores how transnational historical approaches towards gender can provide a fresh perspective to locate women's histories of colonial India and how such enquiries can widen the scope of exploring the rich archival sources available. By bringing in the recent scholarship in the area of gender and transnatioanal history, this paper would demonstrate the possibilities to unearth complex and entangled histories of women by bringing to the discussion the community consolidation efforts of Ezhavas, an erstwhile untouchable caste in the colonial Kerala, in the late nineteenth and early twentieth centuries. Focusing on the transnational character of the cultural and ideological transactions that shaped the Ezhava community mobilization in the wake of colonial transformations in the region, the paper would trace the specific ways in which such exchanges shaped the history of gender within the Ezhava movement. In doing so, this paper would point towards the need to go beyond both colonial and nationalist paradigms to unpack the intricate histories of gender, caste and regional social movements during the age of empire.
\end{abstract}

Keywords: Gender, Social Reform, Caste, Social Movement, Modernity, Transnational History

\section{Introduction}

Global and transnational historical approaches have been expanding the scope of exploring women's and gender histories and such approaches opened up new possibilities of exploring how cross-cultural and cross-border interactions, institutions, ideologies, and networks shape gender and women's histories (Ballantyne and Burton, 2005). Foregrounding such sites of interactions and exchanges in exploring historical formations of gendered identities, such scholarship has also moved beyond the "inward looking-nation based" ways of doing history (Carlier, Midgley, and Twells, 2016, p.1). Such scholarship has contributed towards tracing entanglements within the histories of gender by exploring the social, cultural, economic formations that constituted gendered subjectivities outside the grand narratives of national and colonial history. Histories of different regions that were thought to be distinct in their own right have been shown to be interconnected, entangled, and shaped by various transnational and cross-cultural exchanges in determinate historical conditions. The social, cultural, and political histories of specific regions and 
social groups have been foregrounded in such attempts to locate the gendering process beyond the boundaries set by the dominant accounts on gender and women's histories.

Colonialism is one of the significant forces that animated the permeability of borders and exchanges between nations, cultures, religions, and social groups. The historical experience of colonialism has even defined our understanding of the nation-state and its very borders. Transnational approaches in the historiography of colonialism and nationalism have been restructuring how such histories have been centred on grand narratives of nation and empire. Historiographical frameworks that conceive colonial history as the single encounter between the coloniser and the colonised have been contested by recent scholarships, arguing that colonial encounter is not a homogenous narrative of colonial domination and native resistance to colonial domination (Aloysious, 1997). It was further argued that the cultural contact during the period of empire and the resultant processes of cultural exchange, borrowing, fusion, and appropriation was not a homogenous experience across different regions and communities (Reghu, 2010).

Recent scholarship on the global and transnational histories has been contesting both the linear and progressive accounts associated with the history of imperialism and the homogenised and nation-bound histories of nationalist resistance to focus on how grassroots movements and social groups at different cross-points of marginality experienced colonial encounter, industrialisation, capitalism and manifold interactions enabled by transactions across borders, cultures, and communities. The legacy of such interactions and exchanges, as argued by Tony Ballantyne and Antoinette Burton, "is at the heart of what it is to be modern, what it is to be human, at the start of the twenty-first century"(Ballantyne and Burton, 2005, p.1)

Not only did such a historical vision bring into light fascinating histories of communities, cultures, and ideologies - drawing from each other across borders, shaping social movements, identities, and social transformations- but also how such histories transformed the dominant modes of historicising gendered formations. Harris Kesler, in her article on women and work, moves away consciously from Eurocentric approaches of tracing the history of industrialisation to emphasize the question of how industrialisation transformed women's work in relation to the rise of textile mills in the nineteenth century Lowell (Kesler, 161).

Merry E. Wiesner-Hanks in her reflection on the emergent body of scholarships that draws from both transnational and gender histories explores how this new research interconnects the "subject matter, theory and methodology in transnational history and the history of gender and sexuality" (Weisner, 2011, p.357). She argues that such researches destabilise binaries, emphasising "intertwinings, relationships, movement and hybridity" and this is enabled by the interdisciplinarity and stress on multiple perspectives by both the fields of transnational history and gender history (Weisner, 2011, p.357).

Though colonialism is not the only force that opened up possibilities for cross-border, cross-cultural contact, it remains one of the significant moments in the history of nineteenth and twentieth-century India in general and women's and gender history in particular. Colonial modernity, industrialisation, missionary encounter, the spread of print culture, and various other forces played a significant role in the engagement of various communities in the processes of modernisation. This moment of modernisation is significant in the history of gender. Emphasis on such transnational and transcultural contacts would bring forth more contextualised histories of 
3 | Entangled Histories: Gender and the Community Mobilisations of the Ezhavas in Colonial Kerala

gender outside the imperial-nationalist binary. It is through exploring the fragmented nature of imperialism and other region-bound movements like nationalism, transnational historical approaches locate how colonialism and nationalism are mutually reconstituted and reshaped by each other (Ballantyne and Burton, 2005). Such a framework that enables the fragmented rendering of nationalist and colonial histories would then open up possibilities to unearth women's histories in which women mostly do not figure as historical agents on their own.

Carlier, Midgley, and Twells argue in the introduction to the essay collection edited by them titled Women in Transnational History: Connecting the Local and the Global, which is regarded as one of the significant works in the area of gender and transnational history, that one of the focuses of such scholarship is to overcome "inward-looking nation-based studies of women's lives and the grand narratives of globalisation which, with their focus on 'macro' levels of analysis, lose sight of the grounded 'micro' realities of everyday lives and of the role of human agency in effecting change. They also point out how these fresh perspectives from below are significant in bringing forth the histories of communities that are reduced to a marginal space in the mainstream historiographies (Carlier, Midgley, and Twells, 2016). Transnational perspectives on the study of women's history open up possibilities to explore how "cross border connections and global developments have shaped diverse women's lives and the gendered social, cultural, political and economic histories of specific localities" (Carlier, Midgley, and Twells, 2016, pp. 1)

\section{Transnational Encounters and the History of Gender in Colonial India}

Gender history in colonial India is often traced in terms of the power relations between the dominant masculine figure of the colonizer and the subordinated masculinities and femininities of the colonized. Even inquiries that surround the "gendered construction of colonialism and nationalism" have focused largely on women's questions within the nationalist and religious reform movements during the period (Sinha, 1999, p.446).

Post-colonial feminist scholarship has emphasized how women's agency was subverted by both colonial and indigenous patriarchal powers and has critically engaged with western women's engagements with Indian women, characterizing such engagements as imperialist- feminist in nature. Such studies have also argued that cross-cultural and cross-border exchanges, including missionary initiatives, were inherently shaped by the power imbalances between the colonized and the colonizer. But recent scholarship in the area of gender and transnational history has presented a nuanced and complex history of the agency of women in colonial India and shown how colonial modernity, missionary encounter, and various other economic, cultural, and ideological exchanges across borders opened up new possibilities for women and shaped the gendered social, political and cultural histories of specific localities and communities. Such studies, "instead of presenting women as simply the victims of powerful transnational forces for change, throw new light on the variety of ways in which indigenous, subaltern and non-western women carved out new spaces to assert agency" (Carlier, Midgley, and Twells, 2016, p. 3).

Feminist scholarship on the history of gender in the context of colonial Kerala has explored how social reform emphatically re-constituted older gendered spheres in new forms. Focusing on the redefinition of gender roles during the social reform movements in Kerala from the late 
ninetieth to the early twentieth century, it has been argued that the reform movements of this period were also a process of the reconstitution of existing patriarchal structures. 'Ideology of modern gender' was constituted by presupposing a division of the world into public and private domains corresponding to the place of men and women respectively and drawing from the earlier systems and values, remoulding and refiguring them and replacing the existing social order of caste (Devika, 2006). The nascent public sphere of colonial Kerala, characterized by the reformist social energy, reconstituted the gendered constitution of social domains rather than undermining them, resulting in the relegation of women into a modern domestic realm where they could also negotiate to be in the public realm to a certain extent.

However, the questions of how social groups at different cross-points of marginality in specific experienced this modern identity formation, including the possibilities it opened up, and how did women of marginalised communities redefine their identities as gendered subjects in the context of social transformation are inadequately explored in gender historiographies. One of the significant works which provide us with an insight in this direction is Sanal Mohan's work on slave castes and their engagements with missionary Christianity. He observes that the relatively blurred gender division within the slave caste community was consciously transformed in favour of the secure family structure with a male head.

Although appearing as a contradictory situation, it seems that the liberation from caste slavery and establishment of a secure family structure demanded that the slave-caste communities transcend the abjection of emasculation and attain "manhood" to articulate their desire for social advancement. It appears as a major project in which slave-caste women were deeply engaged (Mohan, 2017, p.55).

It would seem that these gendered family formations were inseparable from their aspiration for social mobility. This new gendered reorganization, as argued by Sanal Mohan, "did not undermine the agency of slave caste women altogether" (Mohan, 2017, 56). He also points out how scholarship on gender and women's history often ignored the encounter with missionary Christianity as a site to locate formations of new gendered subjectivities and women's agency.

One significant aspect of this missionary moment is that extremely ordinary women could achieve worth and self-fulfilment on account of their resourcefulness derived from their role in prayer meetings, among other things. Explicitly recalled in the context of local resistance to caste oppression, these women evinced a leadership role that spurred even men in the local community to confidence (Mohan, 2017, p.56).

The diverse ways in which social change was imagined and conceived by diverse social groups and the specific ways in which women belonging to such social groups engaged with these processes are often missing in colonial historiography. It is due to the dominant understanding of such processes as "insular national or territorially based phenomena" (Ballantyne and Burton, 2005, pp.2)

It is this limitation that the scholarship in the area of gender and transnational history tries to overcome. In this direction, later sections of this paper would explore the implications of the ideology of modern gender or the process of 'engendering' for various communities located at multiple cross-points of marginality and how specific moments of the cross-border and cross- 
5 | Entangled Histories: Gender and the Community Mobilisations of the Ezhavas in Colonial Kerala

cultural engagements of these communities and women, in particular, can be sites to locate specific formations of gender within marginalized communities.

\section{Colonial Encounter and the Community Mobilisation of Ezhavas}

Ezhavas were an untouchable caste group who were mostly toddy tappers and agricultural labourers. Governed by the practice of caste-based pollution and defilement, they were denied entry to the schools, government services, public roads, and temples. Their struggles against untouchability and caste-based social structure acquired a certain momentum during the colonial period and culminated in the formation of an organized movement during the late nineteenth century. For their organized action against the caste Hindu social order, they drew benefits from the changing socio-economic and educational conditions under colonial rule.

Ezhava movement as a collective action against the caste-based social condition was the result of various socio-political and economic transformations bought about during the colonial period. The emergence of a middle class among Ezhavas was one of the major factors that contributed to the organisation of such collective social action. Along with toddy tapping, which is generally known as the traditional occupation of Ezhavas, a large chunk of the Ezhava population were agricultural labourers and some of them were land owners. Some were also engaged in coir making, weaving, trading, business, law, etc. Ezhava community's engagements with diverse occupational sectors in keeping with the changing economic conditions enabled some of its members to become industrialists.

The establishment of British capitalist industries, investing in both plantation and smallscale industries, along with the commercialisation of the economy opened up new avenues for Ezhavas. While other dominant communities which were less experienced in the area of trade and commerce kept a distance from the new opportunities provided by economic transformation, Ezhavas and Christians, without the challenges from upper caste communities, concentrated on profitable manual labour and industrial activities (Chandramohan, 2016, p. 43). They became an integral part of the changing economy. The commercialisation of agriculture transformed lower caste agricultural workers into wage labourers. British Indian territories like Ceylon and Mauritius, where skilled and unskilled labour were needed, opened up the transnational market for lower castes and Ezhavas could take advantage of this opportunity as well (Chandramohan, 2016, p. 48).

Not only did the Ezhava community engage with different occupational sectors to expand their terrains of mobility, they actively engaged with different social groups and communities who were agents of social change. Missionary activities were one of the significant factors that acted as a catalyst to the community mobilisation of the marginalised communities like Ezhavas. Missionary interest in the abolition of slavery and initiatives to uplift the lower castes were also tied up with the emerging capitalist industries. Ezhavas also were able to make use of the educational opportunities opened up by the missionaries. The breast cloth movement among Ezhava and Nadar women in Travancore for the right to cover their breasts with upper-body clothes and Ezhava women's protest against the oppressive breast tax in Travancore are some of the significant moments in the history of social change in colonial Kerala. These aspects of the missionary moment are often ignored by the scholarship on gender in colonial India "though it is 
one of the significant moments where extremely ordinary women could achieve worth and selffulfilment" (Mohan, 2017, 56).

The status and wealth that Ezhavas acquired and their investments in the industrial sector resulted in the emergence of a middle class among them. Though this middle class was a minority, their presence enabled Ezhavas to start a collective movement to challenge the caste-ridden social order. The character of the material and social progress differed across regions and this difference had implications for the formation of gendered identities in these regions. When women's property rights became a pressing question for Ezhavas in the princely states of Kochi and Travancore, their counterparts in British Malabar argued that women's property rights need not be an issue of immediate concern. Questions and formations of gender were contingent upon specific material and social arrangements within the community located in different regions. The emergence of the structures of colonial modernity, industrialisation, missionary activities, and print culture are some of the significant factors and forces that played crucial roles in defining such arrangements that may have shaped the discourse of gender in specific ways. It is to bring forth such underlying layers in the formations of specific gendered identities that the frameworks of transnational history have been adopted in the scholarship on gender.

Ezhava movement is often located within the larger rubric of social reform which in turn is counted as a subset of the nationalist movement. The need to relocate the history of the Ezhava movement from the larger category of social reform to understand how such instances of community mobilizations can be understood as "radical instances of de-imagining nation through autonomous construction of a modern community" has been a point of inquiry for many scholars (Reghu, 2010, p.49). The discourse of the Ezhava movement is centred on two categories of Samudayam (community) and Samudayavalkkaranam (communitization). Sahodaran Ayyappan, one of the leaders of the Ezhava movement, elaborated why Ezhavas chose community over the idea of the nation. He writes:

The idea of community is being ridiculed by the nationalists. But, I am proud of being a spokesperson of the community. I am ashamed of being a nationalist because nationalism is deceptive and it is a strategy to maintain the upper caste hegemony. I have been criticized for not participating in the freedom struggle. I was more concerned with "other" freedoms of the people rather than political freedom. (Reghu, 2010, p.51).

Mithavadi, one of the Ezhava-run magazines during the period drew from various liberation movements across the world to conceptualise the notion of community and to form the course of the movement. The speeches of Booker Washington, the black American leader, and reformer, are often quoted in the magazine. Mithavadiurged all Ezhavas to read his biography. Parallels are often drawn between slavery and the caste system. Liberation movements of Black Americans are often compared to the struggle of oppressed castes under the dominant castes. Educational achievements are identified as one of the significant reasons by which the black community organizes itself. Mithavadiargues that Ezhavas as a community should be able to acquire resources; material, educational and spiritual, to shape their course of the struggle to emerge as an independent community as the Black Americans. Black Americans were able to challenge white dominance because they had no dependency on their oppressors. They ran their own businesses so that there is no financial dependency. They had their own magazines and 
7 | Entangled Histories: Gender and the Community Mobilisations of the Ezhavas in Colonial Kerala

newspapers to voice their concerns and their own places of worship. They also had strong leadership. Ezhava movement found these aspects of the Black movement as something that their movement could also take up. Interestingly, Ezhavas placed the dominant castes as their oppressors, and colonialism is often seen as a condition that can be used to mobilize against the internal colonizers. Vivekodayam and Mithavadi, two significant Ezhava-run Magazines often drew from various other ideologies and nationalities with progressive social worlds to shape their collective action against the dominant castes.

\section{Women in Ezhava Movement: History of Gender and Transnational Entanglements}

With the formation of SNDP (Sree Narayana Dharma Paripala Yogam) in 1903 under the leadership of a charismatic ascetic figure like Narayana Guru, the Ezhava movement entered a significant and organized phase. Ezhava women played a significant role in shaping the movement and women marked their presence in the colonial public sphere as active agents of modernization (Sreebitha, 2015). SNDP had a separate all-women organization Sthree Samajam. Sreebitha P V, in her analysis of Ezhava women-run magazines during the period, argues that the concerns and priorities of Ezhava women were distinctly marked and were different from women of other privileged communities in matters of caste, religion, nation, and freedom (Sreebitha, 2015). Ezhava women at that point were envisioning how, as women, they should contribute to the community and its progress. They also argued for their rightful part in the leadership of the movement which is mostly taken over by the male members of the community.

Ezhava women actively wrote in community-run magazines like Mithavadi and Vivekodayam and there were also women's magazines like Sanghamitra and Sahodari. In a meeting organized by Sthreesamajam, K Gouri amma who secured a bachelor's degree from Madras Presidency College, the first woman from the community to graduate, was felicitated. In her thanksgiving speech delivered in English, she said:

I think I am perfectly justified in saying that in awarding me this token of esteem you are laying on me a heavy responsibility; you are as it were, awakening me to a higher sense of my duties towards my sisters of the community. I can assure you that I will attempt all I can to foster their interests. It is my earnest desire that our community should produce many more women graduates and I feel rather confident that the encouragement and attention the S.N.D.P Yogam has begun to show in this connection will not fail to produce a glorious result that will eventually bring our community forward to take its place in the front rank of communities (Mithavadi, 1916)

Women's education was identified as an important prerequisite for the community's progress and also to ensure the proper upbringing of the children. Most of the Ezhava women were educated in mission-run schools as government schools did not allow their presence. Even after government schools became legally accessible to them, the opposition from the dominant castes and high fees prevented women from being admitted.

Karayi Damayanthi, one of the leaders of the Sthree Samajam, in one of her speeches delivered at a Sthree Samajam meeting in 1916 brings in stories of women across the world who intellectually challenged their male counterparts in various fields. She brings these examples to 
refute the claim of the intellectual superiority of men over women by men both within and outside the community.

She says that the popular belief that a woman's brain is smaller than that of a man is being disproved by scientific researches in Britain. Women have succeeded as lawyers, engineers, and scientists in America and Paris. They have intellectually challenged men in their respective fields. An American woman engineer named Ms Greef has earned the respect of the world through her achievements in the field of engineering that is dominated by men. To challenge the male dominance within the movement and outside, Ezhava women drew from the lives and achievements of women across the borders.

Karayi Damayanthi's daughter C K Revathi Amma was also an important figure within the public politics in the colonial North Malabar. In his introduction to C K Revathi Amma's autobiography, Sahasrapoornima Moorkoth Kunpappa talks about how her entry into the public politics in French-governed Mayyazhi in present North Kerala was influenced by the emerging spirit of community movements as well as the influence of the transnational trans-cultural interactions and associations. Moorkoth Kunjappa comments:

The positive aspects of western culture need to be incorporated into Indian culture and the driving forces of western culture influenced Revathi Amma too as they influenced all other Indians. The influence of French culture that was not much available in many parts of India was imparted to Revathi Amma through her husband's and her life at Mayyazhi. Revathi Amma's public activity flourished in an all-encompassing atmosphere (Kunjappa, 1977, p. VII)

It is interesting to see how Kunjappa identifies Revathi Amma's identity as a reformer figure in the larger context of the Ezhava Movement as also shaped by her interactions and associations with transnational, transcultural spaces in the French-governed Mayyazhi.

As Kunjappa points out, French culture and governance had a defining role in the shaping of Revathi Amma's public life as an important figure within the public politics in Mayyazhi in general and among the Thiyya community in specific (Thiyya and Ezhava are sub caste distinctions among the community specific to Malabar and Travancore respectively). Kunjappa also says that an untouchable community like Thiyyas remained a very influential community in Mayyazhi. C K Revathi Amma's husband was educated in Pondicherry, another French-governed region during the period, and was later the commissioner in the French Police. Her husband's uncle was the Mayor of Mayyazhi for several years. French governance in Mayyazhi is one of the reasons why caste groups like Thiyyas could acquire colonial education and higher positions in the government services unlike in the past.

Revathi Amma's entry into public politics was by organising a drama performance by girls to raise funds to help those who are injured in the war as part of the French army. An organisation called Red Cross Society was founded in Mayyazhi in a meeting called by the governor to collect funds to help those who are injured in the war. Though Revathi Amma's husband was not so supportive to her organising activities at the Red Cross Society thinking how she might manage responsibilities at the home and looking after of children along with these public activities, with the support of her uncle, mayor of Mayyazhi who was made in charge by the government for the 
9 | Entangled Histories: Gender and the Community Mobilisations of the Ezhavas in Colonial Kerala

fund collection, she successfully managed to organise the drama performance. The meeting to constitute Red Cross Society in Mayyazhi was the first public meeting which women could be part of, as Revathi Amma narrates. She later became a strong presence in the public politics of Mayyazhi through organising Mahila Samajam, a community-based effort to work among women. Mahila Samajam was an early initiative by her mother Karayi Damayanthi in Thalassery to uplift the condition of women. She also ran a library, organised women, and trained them to enter into small-scale, income-generating professions. Karayi Damayanthi's father was a prominent figure in Thalassery who had direct trade relations with England and many other places.

C K Revathi Amma's associations with Red Cross Society and French women who were active in the Red Cross Society were crucial in facilitating her autonomous initiatives to uplift women in the community. Revathi Amma's life as a pioneering feminist figure in Colonial Malabar should be understood in terms of how she negotiated her public life as an important figure within the community movement through her associations with the missionaries, the colonial government, and Red Cross Society. It can be argued that a fresh transnational perspective into her life can open up possibilities to explore the significance of cross-cultural and cross-border exchanges in the shaping of Revathi Amma's identity as a public figure. It also reveals the limitations of dominant practices of historicisation of women's lives, activism, and public engagements that often overlook such diverse engagements through which marginalised women shape their space within the colonial public sphere.

Sanghamitra, an Ezhava-run women's magazine during the period carried a separate column titled 'Woman's World' (Sthree Lokam) wherein stories, debates, life histories, incidents, and movements concerning women and gender were brought in for discussion. A report in the column Sthree Lokam talks about how a famous novelist in Ireland named Miss Risegreemsha lived amongst a Cannibal community for 15 years to undertake a study of the community and came back. Sanghamitra also carried reports on the slave trade in Hong Kong and how young girls are sold in public places, new bills passed in New York about the pregnant women in jail, death of Missis Unisimon, the first woman from India who went to South Africa as a missionary, census in Italy which reported that women are more in population than men in Italy and many more reports and stories that concern women (Sanghamitra 1921).

Marriage practices and debates around marriage across the world are some of the themes around which many reports are written. One of the reports says "In most of the regions men ask women permission for marriage, but in New Guinea, women ask men if he is willing to marry her" (Sanghamitra 1921). Another report on a public debate that happened in Washington talks about how the debate concluded that it is better for women to remain unmarried.

Motherhood is one of the central themes around which the idea of the modern woman is constructed in Sanghamitra. One of the reports in this regard is the one about Letizia Bonaparte, mother of Napoleon. Motherhood and its importance in the construction of the image of modern woman are being elucidated through talking about how educated and learned women can better the growth and development of the younger generation. Being a widow who is not rich and educated, Letizia raised her 8 kids and her self-determination in managing the family and raising her children, her bravery and mental strength are something that all women should thrive to inculcate according to Sanghamitra. 
In another article titled "Adhunika Sthreekalod" (To Modern Women), Mundakkal Meenakshi Amma writes:

We have to think about how western countries like America and Europe achieved progress within a century. What resulted in their progress is their unity and interest in the matters of agriculture, trade, and handicraft. Dear sisters, we are half of the world's population. Would we achieve the progress and mobility we desire if only men put in hard work and effort? Many women accept Grihabharanam (administration of home) as our work and modern women should not be satisfied with that kind of work alone. There are ample amount of possibilities for women to acquire honour and money. The call to boycott foreign cloths can be made in our favour by investing ourselves into cotton cultivation and weaving which can go hand in hand with home management and child care. We should be part of agriculture and trade (Sanghamitra 1921, Vol.2, p. 37)

It is important to note how the idea of progress and mobility in general and women's role in the community's progress and mobility in particular, are being spoken about by bringing in histories of other regions across the world. B N Kalyani Amma in her speech transliterated in Sanghamitra says:

Complete freedom is what Ezhava community should demand now. Everyone has the right to freedom and no one has the right to deny it, not communities to its members, priests to their followers, men to women, rich to poor, whites to the colored. What is women's role in acquiring freedom? In the early stages of the world, progress was inherited from women. But later women became mere creatures in the kitchen, idols to be worshiped and birds to be caged. But things are getting better across the world. In Russia, France, Australia, and the United States women are at the forefront in dealing with public matters, especially those that concern women. In Russia, countless women participated in the freedom struggle (Sanghamitra 1921, Vol. 7).

Kalyani Amma also brings in histories of progress and mobility women have achieved across the world to reflect upon the idea of mobility and progress of the Ezhava community and the women within the community. It is interesting to note how women's writing on progress and mobility moves beyond the politics of the nation and the empire.

The gradual change in how gender relations are perceived can be noted by looking at the transnational orientation of the writings of these women and this can be located as a moment of transition within the history of gender in colonial Kerala. It is these nuances within the history of gender that are often glossed over in the colonial historiography of gender and this paper has been demonstrating how rich sources of women's writing and life histories need to be relocated and analysed through a fresh transnational historical perspective. Such a perspective which takes into account the transnational and transcultural aspects of the gender history and recognises the constellation of forces at play in shaping the experience of colonial modernity can bring forth fresh frameworks through which specific histories of women and gender can be located and understood beyond the privileged binary categories around the politics of colonialism and nationalism. 
11 | Entangled Histories: Gender and the Community Mobilisations of the Ezhavas in Colonial Kerala

This paper, by bringing in women's writings and life histories from the specific context of the community mobilisation of Ezhavas in colonial Kerala, has attempted to explore how transnational spaces, interaction, fusion, borrowings, and intermixing shaped women's agency and politics even within the sphere of community movement. Women's sense of agency and their engagements with the wider society in the colonial period can be better explored by bringing in fresh historical perspectives and this paper suggests transnational perspective as a significant approach to historicise complex relationship between gender and modernity. This paper also suggests that explorations into the rich archival sources on gender and women's history in the colonial period to locate transnational spaces of interactions and exchanges can uncover the arrays and depths of women's activism during the colonial period.

\section{References}

Aiyappan, A. (1994). "Iravas and culture change". Bulletin of the Madras Government Museum vol. 5, no. 1. Government Press.

Aloysius, G. (1999). Nationalism without a Nation in India (Oxford India Paperbacks). Oxford University Press.

Balakrishnan, P.K. (1954). Narayanaguru.DC Books.

Balan, M. (2010). "The Thiyyas of Northern Kerala". Janasamskara Padananghal. (Studies on the People and Culture). Janasamskara Padana Kendram, 97-104.

Ballantyne, T., \& Burton, A. (2005). Bodies in Contact: Rethinking Colonial Encounters in World History. Duke University Press Books.

Devika, J. (2007). Engendering Individuals: The Language of Reforming in Early Twentieth Century Keralam. Orient Logman.

Kumar, Uday. (1997). "Self, Body and Inner Sense: Some Reflections on Sreenarayana Guru

Logan, William. (2004). Malabar Manual. New Delhi: Asian Educational Services.

Menon, Dilip M. (1994). Caste, Nationalism and Communism in South India: Malabar, 1900 1948.Cambridge U P.

Merry Wiesner-Hanks. (2005). "Women's History and World History Courses," Radical History Review.91, 134.

Midgley, C., Twells, A., \& Carlier, J. (2016). Women in Transnational History: Connecting the Local and the Global (Women's and Gender History) (1st Ed.). Routledge.

Mohan, Sanal. (2017). "Women and Religiosity: Dalit Christianity in Kerala". Economic \&Political weekly, vol. I, no. II, pp. 50-57

P.V, Sreebiha. (2015). “Ezhava Women's Magazine: Addressing Issue of Community, Reform and Nation" in Feminism and Literature: Text and Context, Sanjeev Kumar Vishwakarma, Ed. Takhtotaaz.

Reghu, J. (2010). "Community as De-imagining Nation: Relocating Sree Narayana Movement in Kerala" .Ed. Ravi Raman. (2010). Development Democracy and the State: Critiquing the Kerala Model.

Routledge. 
Roberts, Mary. (2005). "Review: The Trans-nationalization of Gender History", History and Theory, Vol. 44, No. 3, pp. 456-468.

Zacharia, Scaria, ed. (1996). Thalassery Rekhakal.Centre for Kerala Studies.

\section{News Papers and Periodicals}

Mithavadi 1913-21

Sahodaran 1920-22

Sanghamitra 1921

Vivekodayam 1903-1936

PhD Scholar in Gender Studies at the Centre for Women Studies, University of Hyderabad, India. Research interests include Community Movements, Gender and Anti-caste Movements, Histories of Masculinities and Femininities within Social Movements, Women's Autobiographies and Translation Studies. 